DOI: 10.17805/ggz.2017.6.10

\title{
Онлайн-программа сравнительного тезаурусного анализа русских переводов произведений У. Шекспира: итоги первого года"
}

Б. Н. Гайдин

Московский гуманитарный университет

В статье представлены некоторые итоги первого года работы над проектом «Разработка и внедрение в открытом доступе онлайн-программы сравнительного тезаурусного анализа русских переводов произведений У. Шекспира» (www.shakespearecorpus.ru), поддержанным грантом РФФИ (№ 17-04-120386). Автор перечисляет основные возможности платформы на примере сравнения переводов пьесы «Троил и Крессида» У. Шекспира, выполненные в XX-XXI вв. А. М. Федоровым, Л. С. Некорой, Т. Г. Гнедич и А. В. Флорей.

Ключевые слова: У. Шекспир; русские переводы Шекспира; тезаурусный анализ; проект Version Variation Visualization; цифровая гуманитаристика; «Троил и Крессида», А. М. Федоров, Л. С. Некора, Т. Г. Гнедич, А. В. Флоря

\section{Digital Tools for Comparative Thesaurus Analysis of Russian Transla- tions of W. Shakespeare's Works: Results of the First Year \\ B. N. Gaydin \\ Moscow University for the Humanities}

The article comprises some results obtained during the first year of the "Development and Launching of Open Access Online Digital Tools for Comparative Thesaurus Analysis of Russian Translations of W. Shakespeare's Works" project (www.shakespearecorpus.ru) supported by the Russian Foundation for Basic Research (no. 17-04-120386). The author specifies the main opportunities provided by the "Version Variation Visualization" platform using the case of Russian trans-

\footnotetext{
* Статья подготовлена в рамках проекта «Разработка и внедрение в открытом доступе онлайн-программы сравнительного тезаурусного анализа русских переводов произведений У. Шекспира», осуществляемого при поддержке РФФИ (№ 17-04-12038в).

The article was prepared within the framework of the project "Development and Launching of Open Access Online Digital Tools for Comparative Thesaurus Analysis of Russian Translations of W. Shakespeare's Works" with support from the Russian Foundation for Basic Research (no. 17-04-12038в).
} 
lations of Shakespeare's "Troilus and Cressida" made in the 20th-21st centuries by A. M. Fedorov, L. S. Nekora, T. G. Gnedich and A. V. Floria.

Keywords: W. Shakespeare; Russian translations of Shakespeare; thesaurus analysis; "Version Variation Visualization" project; digital humanities; "Troilus and Cressida"; A. M. Fedorov; L. S. Nekora; T. G. Gnedich; A. V. Floria

\section{ВВЕДЕНИЕ}

В 2018 г. исполнится 270 лет «Гамлету» А. П. Сумарокова (Сумароков, 1749) - вольной переделке одноименной шекспировской трагедии, которую он выполнил в 1748 г. по французскому пересказу П.-А. де Лапласа (1745). Именно с нее обычно отсчитывают историю переводов наследия У. Шекспира в России. Позже были осуществлены первые попытки дать русскоязычным любителям словесности возможность читать произведения Шекспира на родном языке (Н. М. Карамзин, И. А. Вельяминов, С. И. Висковатов, М. П. Вронченко, В. А. Якимов). С ростом интереса к Шекспиру число переводов постоянно увеличивалось. В 1840-1860-е гг. появились переводы Н. Х. Кетчера, А. И. Дружинина, Н. М. Сатина, А. А. Григорьева, П. И. Вейнберга и др. В 1894 г. были опубликованы прозаические переводы Шекспира П. А. Каншина (Шекспир, 1894). А. Л. Соколовский вошел в историю как первый русский переводчик, выполнивший и издавший стихотворные переводы 37 пьес, т. е. всего так называемого «шекспировского канона» (Шекспир, 1894-1898). В 1902-1904 гг. появилось Полное собрание сочинений Шекспира в 5 томах, подготовленное С. А. Венгеровым (Шекспир, 19021904) - итог русской рецепции шекспировского творчества в XIX в.

В советский период тезаурус отечественной культуры значительно пополнился образцами высокохудожественного перевода сочинений Шекспира, выполненными такими мастерами как Ю. П. Анисимов, Т. Г. Гнедич, М. А. Донской, Ю. Б. Корнеев, М. А. Кузмин, В. В. Левик, М. Л. Лозинский, С. Я. Маршак, П. В. Мелкова, Л. С. Некора, Б. Л. Пастернак, А. Д. Радлова и др.

Известно, что каждое новое поколение переводчиков пытается передать шекспировские строки на русском языке в соответствии с духом своей эпохи. За последние три десятилетия с развитием книжного рынка и особенно Интернета было опубликовано значительное количество новых переводов Шекспира разного рода и качества, которые еще ждут своих критиков и исследователей (например, переводы В. З. Ананьина, Г. Е. Бена, Г. М. Кружкова, Ю. И. Лифшица, И. В. Пешкова, В. Р. Поплавского, О. П. Сороки, И. К. Тюриковой, В. Я. Тяптина, А. В. Флори, А. Ю. Чернова и др.). Корпус шекспировских переводов на русском языке представляет собой уникальный 
материал для анализа, поскольку в нем находят свое отражение различные пласты русской и мировой культуры, диалог культур и эпох, прошлое и настоящее.

До настоящего времени в отечественном шекспироведении не было предпринято ни одной попытки комплексного текстологического изучения истории шекспировских переводов на русский язык. Известны лишь отдельные научные работы, в которых рассмотрена история русскоязычных переводов шекспировских сонетов и отдельных пьес. Некоторые из них уже утратили свою актуальность в связи с появлением новых переводов. Число научных работ, в которых применяется текстологический анализ шекспировских переводов на русский язык, невелико. Лишь в сравнительно небольшом количестве работ он выполнен на должном уровне. Далеко не все русские переводы Шекспира были вообще когда-либо проанализированы с точки зрения текстологии (см. подробнее: Гайдин, 2015).

\section{ОНЛАЙН-ПРОГРАММА СРАВНИТЕЛЬНОГО ТЕЗАУРУСНОГО АНАЛИЗА РУССКИХ ПЕРЕВОДОВ ПРОИЗВЕДЕНИЙ У. ШЕКСПИРА}

Для решения этой проблемы был задуман проект «Разработка и внедрение в открытом доступе онлайн-программы сравнительного тезаурусного анализа русских переводов произведений У. Шекспира». В основе разработанной программы - код платформы Version Variation Visualisation (VVV). Она доказала свою эффективность при исследовании текстов на английском, немецком, чешском, польском, испанском, португальском языках, а также на иврите (см., например: Чизман, 2015; Cheesman, 2010, 2011, 2015; Cheesman et al., 2016, 2017; Cheesman, Roos, 2017: Электронный ресурс).

Проект призван способствовать интенсификации научных исследований феномена «Русского Шекспира» сквозь призму истории отечественных переводов произведений британского поэта и драматурга. Наличие многочисленных переводов ставит задачу их сравнительного анализа и разработки специальной программы тезаурусного анализа переводов с оригиналом и между собой.

Представляется, что создание и внедрение программы сравнительного анализа позволит помочь значительно упростить процесс текстологической работы над переводами и способствовать появлению новых статей, монографий, диссертаций и т. п., ее применение может повысить качество и глубину новых исследований. Онлайн-программа также способна привлечь внимание студентов и аспирантов и стать полезной при выполнении квалификационных исследовательских работ по данной тематике. 
Задача проекта - максимально полное и всестороннее представление русскоязычных переводов произведений У. Шекспира с возможностью их сравнительного тезаурусного анализа с англоязычными оригиналами и между собой. Для ее решения в 2017 г. была начата работа по созданию компьютерной онлайн-программы, с помощью которой можно было бы удобно сравнивать сегменты текста-источника с соответствующими сегментами переводов в визуализированной среде, наглядно увидеть разницу между переводами, проанализировать индивидуальный стиль переводчиков, используемые ими средства русского языка для передачи языка Шекспира, выявить степень оригинальности перевода, авторские вставки и дополнения переводчиков, которых нет в исходных текстах.

Основная проблема, которая стояла перед нами, заключалась в следующем. Программное обеспечение VVV создавалось изначально для германских языков с их нефлективным строем. Для того чтобы размеченные сегменты перевода точно совпадали друг с другом и с базовым текстом оригинала, было необходимо приспособить инструменты сегментации к структуре русского языка, чтобы сравнение различных вариантов работало более точно.

Текстуальной основой проекта послужили русские переводы Шекспира, размещенные в БД «Русский Шекспир» (www.rus-shake.ru; создана при поддержке Российского гуманитарного научного фонда в 2005-2007 гг., проект № 05-04124238в.). За прошедшие с момента окончания финансирования годы корпус переводов в БД был пополнен целым рядом переводов XVIII-XX вв., а также новыми работами современных переводчиков (с разрешения или по просьбе правообладателей). В данный момент БД насчитывает более 120 переводов (как полных, так и различных отрывков; без учета переизданий). Кроме разработки, внедрения и тестирования программы проект предполагает осуществление специальной метаразметки как имеющихся переводов, так и поиск недостающих русских переводов, находящихся в общественном достоянии.

Каждый год число русских переводов произведений Шекспира увеличивается. Безусловно, в проекте не могут быть представлены абсолютно все новейшие шекспировские переводы в силу действия авторских прав, однако работы некоторых современных переводчиков будут с их согласия размещены на сайте наряду с переводами, находящимися в общественном достоянии.

В конце 2017 г. была протестирована и запущена в Интернете программа сравнительного тезаурусного анализа русских переводов произведений У. Шекспира. Программа размещена по адресу: http://shakespearecorpus.ru/. Для просмотра необходимо нажать кнопку «Войти» или перейти по ссылке http://shakespearecorpus.ru/Account/LogOn?returnUrl=\%2F и нажать «Войти»; данные уже вписаны в соответствующих полях. В случае возникно- 
вения проблем необходимо ввести данные для входа вручную: логин Guest; пароль - Guest2012. Были созданы русская и английская версия программы. Была проведена локализация программы для анализа текстов на русском языке, разработан инструмент сегментации, произведена адаптация программы к морфологическим особенностям русского языка.

В ходе консультаций с разработчиками платформы VVV был определен оптимальный формат базового текста. Он должен основываться на современном научном издании соответствующего шекспировского текста, быть удобным для разделения на сегменты и при этом не представлять собой радикальный текстологический эксперимент редакторов. В качестве источника базовых текстов были взяты версии произведений Шекспира, представленные Фолджеровской шекспировской библиотекой: www.folgerdigitaltexts.org/ download/. Они были подвергнуты переформатированию под нужды проекта. Проблема сегментации текста в ходе консультаций была решена путем максимально возможной объективизации: за сегмент текста принимается целиком реплика персонажа или ее часть в случае смены коммуникативного адресата (что, как правило, в издании оригинала и перевода отражается с помощью ремарок «в сторону», «(обращаясь) к...», «входят...», «...ухходят» и т. п.) В случае, если соответствующий фрагмент перевода сегментирован подругому, соответствия устанавливаются по базовому тексту.

Проект был представлен на трех научных конференциях:

1) IX конференция Европейской шекспировской исследовательской ассоциации «Шекспир и европейские театральные культуры: (ан)атомизация текста и сцены» (Shakespeare and European Theatrical Cultures: AnAtomizing Text and Stage; 27-30 июля 2017 г., Гданьск, Польша). 29 июля 2017 г. В. С. Макаров и Б. Н. Гайдин приняли участие в круглом столе «Национальные репозитарии шекспировских переводов: разбирая/собирая черный ящик» (National Repositories of Shakespeare Translations: (Dis)assembling the Black Box; организатор: Анна Цетера-Влодарчик / Anna Cetera-Włodarczyk, Bapшавский университет) с докладом «Российские шекспировские репозитарии: между местными и глобальными читателями» (Russian Shakespeare Repositories: Between Local and Global Readers; см.: Zakharov, Makarov, Gaydin, 2017). Ссылка на новость: http://world-shake.ru/ru/news/4945.html.

2) LXI августовские Михайловские Пушкинские чтения на тему «...взглядом Шекспира» (23-25 августа 2017 г., Мемориальный музейзаповедник А. С. Пушкина «Михайловское»). Н. В. Захаров представил участникам информационные проекты Института фундаментальных и прикладных исследований МосГУ и рассказал о разработке программы сравнительного анализа русскоязычных переводов сочинений У. Шекспира и воз- 
можностях использования средств платформы Version Variation Visualization (VVV) в исследованиях корпуса русских переводов шекспировских произведений. Ссылка на новость: http://rus-shake.ru/menu/news/14269.html.

3) Международная научная конференция «Актуальные проблемы изучения и преподавания англоязычной литературы» (21-23 сентября 2017 г., Минский государственный лингвистический университет, Беларусь). И. И. Лисович рассказала участникам конференции о трех электронных научных проектах МосГУ, посвященных творчеству У. Шекспира и его современников, а также о новом проекте «Разработка и внедрение в открытом доступе онлайн-программы сравнительного тезаурусного анализа русских переводов произведений У. Шекспира». Ссылка на новость: http://russhake.ru/menu/news/14282.html.

Информация о проекте размещалась на сайтах «Русский Шекспир», «Мир Шекспира», «Современники Шекспира» и др., а также в социальных сетях «ВКонтакте» (https://vk.com/shakespeareinrussia), Facebook (https://facebook.com/around.shakespeare/), Google+ (https://plus.google.com/u/1/+RussianShakespeare) и др.

Рассмотрим некоторые возможности программы на примере переводов шекспировской пьесы «Троил и Крессида».

\section{«ТРОИЛ И КРЕССИДА» У. ШЕКСПИРА \\ В РУССКИХ ПЕРЕВОДАХ ХХ-ХХІ вв.}

Пьеса «Троил и Крессида» (ок. 1602) принадлежит к так называемым «проблемным пьесам» Шекспира по классификации, предложенной в конце XIX в. английским специалистом по драме Нового раннего времени Ф.-С. Боасом. Он считал, что это произведение драматурга наряду с пьесами «Гамлет», «Мера за меру» и «Все хорошо, что хорошо кончается» нельзя однозначно отнести ни к комедиям, ни трагедиям, поскольку их финалы по существу оставляют нам множество открытых вопросов и тайн, поэтому он предложил позаимствовать из драматургии тех лет термин «проблемные пьесы» ("All these dramas introduce us into highly artificial societies, whose civilization is ripe unto rottenness. Amidst such media abnormal conditions of brain and of emotion are generated, and intricate cases of conscience demand a solution by unprecedented methods. Thus throughout these plays we move along dim untrodden paths, and at the close our feeling is neither of simple joy nor pain; we are excited, fascinated, perplexed, for the issues raised preclude a completely satisfactory outcome..."; Boas, 1910: 345). Как отмечал А. А. Аникст, концепция получила развитие: за всеми вышеуказанными произведениями Шекспира, кроме «Гамлета», закрепился термин «проблемные пьесы» (Аникст, 1973: 467-468). 
Кроме указания, что пьеса была поставлена в «Глобусе» при жизни Шекспира («История о Троиле и Крессиде, как она исполнялась его величества слугами, в театре "Глобус"») в одном из двух вариантов опубликованного в 1609 г. кварто, не сохранилось никаких свидетельств о том, что сочинение драматурга ставилось на сцене при его жизни. Скорей всего, если такая попытка действительно была, то успеха у зрителей она не снискала (Смирнов, 1959: 622). Шекспировская пьеса «Троил и Крессида» появилась в репертуаре театров только в начале XX в., к ней сравнительно не часто обращаются современные режиссеры (см., например, список постановок: Troilus and Cressida: Электронный ресурс). В России пьеса также была поставлена лишь несколько раз. Нам удалось найти сведения о постановке в Красноярском ТЮЗе режиссера Ю. А. Мочалова (1969; Гладких, 1969), спектакле Е. И. Еланской в театре «Сфера» (2005), также о работе режиссера Р. В. Туминаса в Театре имени Е. Б. Вахтангова (2008).

В настоящее время большинство собраний сочинений Шекспира, а также отдельных изданий пьесы предлагают комбинированные версии текстов кварто 1609 г. и Большого фолио 1623 г., поскольку в первом издании, по мнению некоторых шекспироведов, есть более «убедительные» места, а во втором некоторые реплики были дополнены (см., например: Bevington, 1998: xviii).

На данный момент нам известны восемь русских переводов пьесы: Н. Х. Кетчера (прозаический; 1866), А. Л. Соколовского (1866), П. А. Каншина (1887), его же прозаическая версия (1893), А. М. Фёдорова (1904), Л. С. Некоры (1949), Т. Г. Гнедич (1959) и А. В. Флори (2008).

На момент написания статьи для сравнения в программе были доступны 4 перевода, выполненные в XX-XXI вв. Самым вариативным переводом является версия А. М. Фёдорова, совсем рядом перевод Т. Г. Гнедич. Работа Л. С. Некоры занимает промежуточное значение, а текст А. В. Флори наименее вариативен по сравнению с работами его предшественников (см. рис. 1).

Режим «Просмотр соответствий» показывает, что все переводчики в целом «бережно» подходили к шекспировскому тексту, хотя и позволяли себе некоторые реплики опускать. Все четыре перевода визуально короче оригинала. Например, в переводе А. В. Флори отсутствует 4 сцена III акта. 


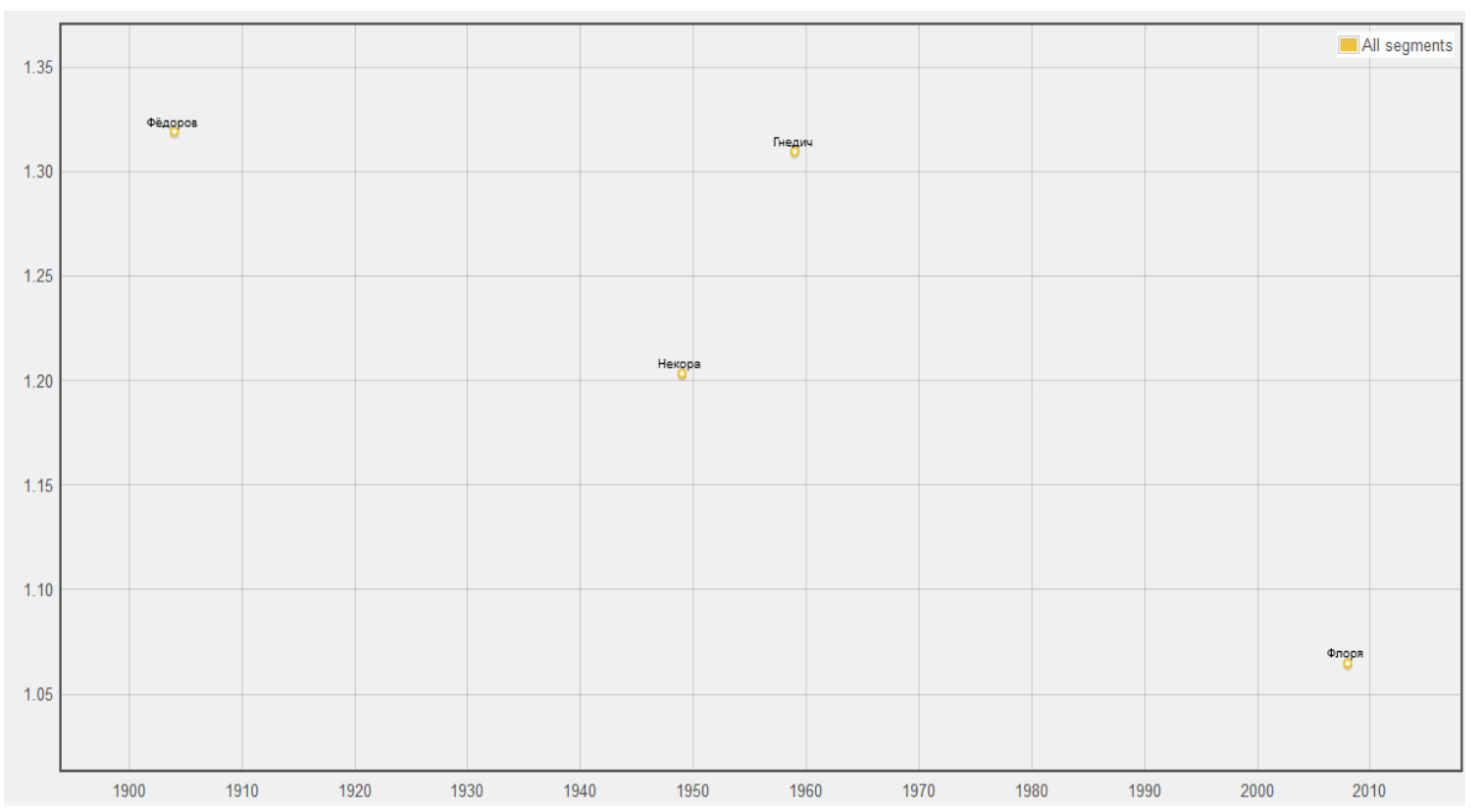

Рис. 1. «Троил и Крессида»—-История Eddy

Этот режим позволяет увидеть места, которые переводчик решил по какой-то причине не переводить, а также те, которые он добавил «от себя». Например, в самом современном переводе А. В. Флори можно найти примеры, когда некоторые реплики героев переведены путем разбивки на смысловые части, при этом некоторые строчки оригинала опущены (например, слова Париса: 'Ay, good now, “Love, love, nothing but love."'), а некоторые реплики наоборот добавлены переводчиком (например, Елена: «А я нет»; рис. 2). Предстоит выяснить, могло ли это быть как-то связано с тем, что была использована другая редакция оригинального текста.

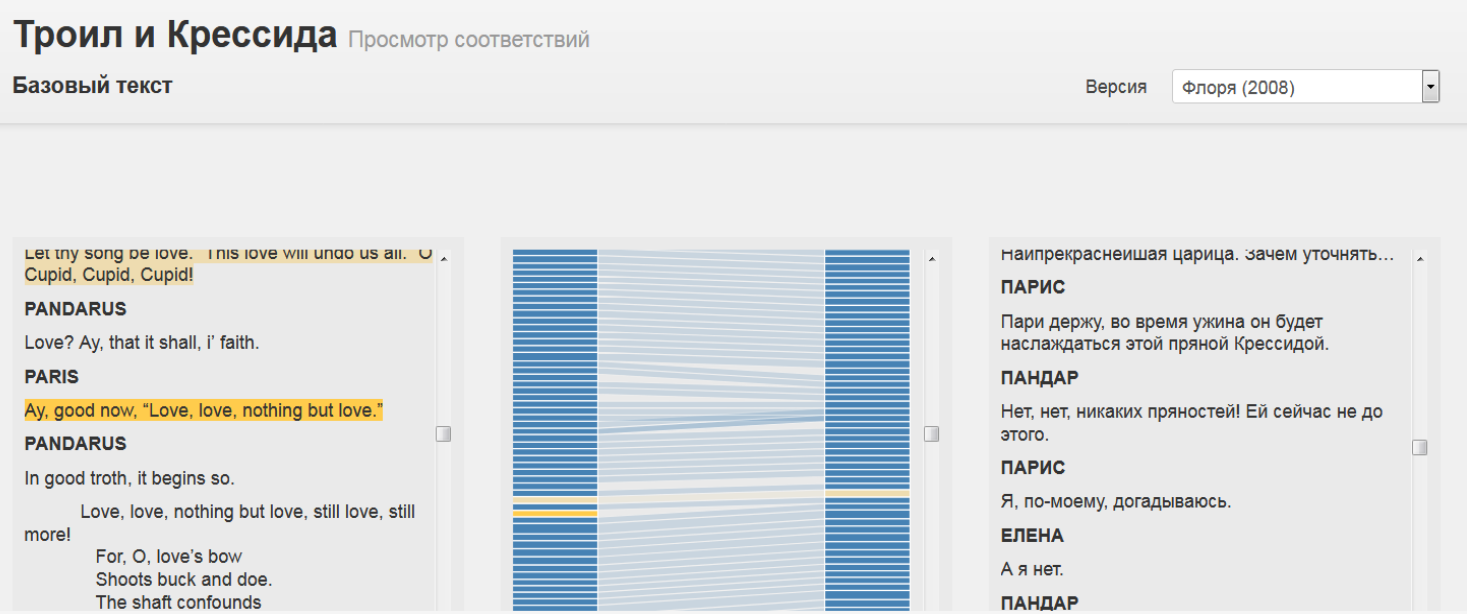

Рис. 2. «Троил и Крессида» в переводе А. В. Флори режим «Просмотр соответствий» 
В режиме «Вариативность» можно выявить наиболее оригинальные переводы отдельных сегментов (рис. 3).

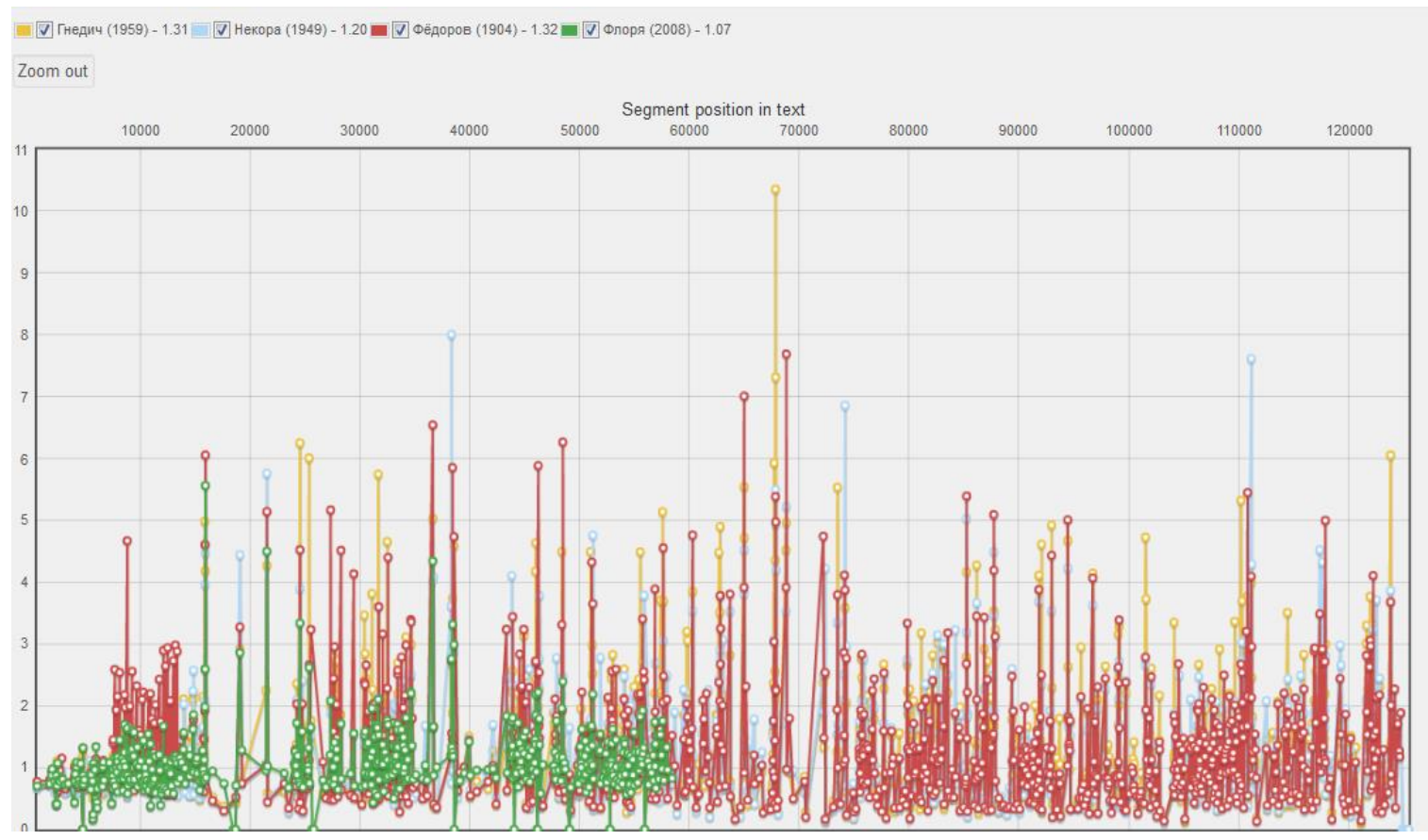

Рис. 3. Корпус «Троил и Крессида» — режим «Вариативность»

Наконец, режим Eddy \& Viv позволяет просмотреть переводы конкретного сегмента и выяснить показатели их вариативности. К примеру, открывающие пьесу слова Пролога наиболее вариативны в переводе А. М. Фёдорова (>0,77; рис. 4), далее следует переводы А. В. Флори $(>0,7)$, Т. Г. Гнедич $(>0,69)$, Л. С. Некоры $(>0,66)$. Ту же последовательность дает и подсчет количества строк: Фёдоров - 39, Флоря - 37, Гнедич - 33, Некора - 32. При этом в базовом тексте - 31 строка.

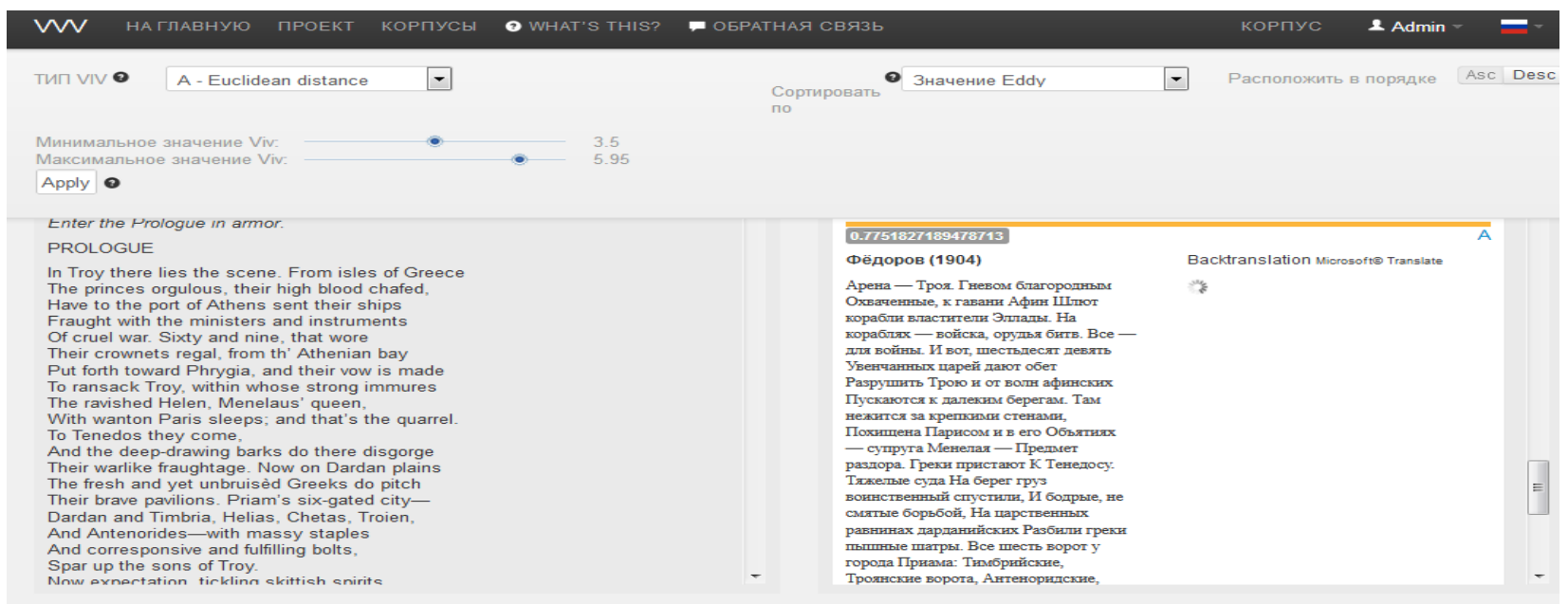

Рис. 4. «Троил и Крессида»-режим Eddy \& Viv 
Безусловно, пока это лишь предварительные данные, которые могут измениться при добавлении переводов XIX в., поэтому более детальный анализ русских переводов пьесы «Троила и Крессида» целесообразнее будет представить в отдельной статье.

\section{ЗАКЛЮЧЕНИЕ}

В 2018 году участники проекта планируют решить следующие задачи:

1) осуществление метаразметки более 110 русских переводов произведений У. Шекспира, размещение их в Интернете по адресу: www.shakespearecorpus.ru;

2) поиск и оцифровка малоизвестных переводов, находящихся в общественном достоянии;

3) поиск современных переводов, переговоры с владельцами авторских прав с целью получения разрешения на использование переводов или их отдельных частей в корпусе переводов;

4) техническая доработка программы, поиск путей для ее развития, изучение поступивших замечаний и предложений;

5) исправление возможных недочетов и ошибок в уже размеченных текстах;

6) привлечение внимания целевой аудитории (переводчики, текстологи, переводоведы, шекспироведы, студенты-филологи и т. д.) к проекту посредством размещения информации о проекте на тематических сайтах, в социальных сетях;

7) подготовка статей для научных журналов и коллективной монографии с демонстрацией возможностей программы для использования в исследовательской практике;

8) представление хода реализации проекта на международных научных конференциях.

В конце 2018 г. мы планируем получить следующие научные результаты:

1) Будет осуществлена публикация в открытом доступе в визуализированной среде более 130 русских переводов произведений У. Шекспира.

2) Будет подготовлена и опубликована в Интернете на тематических сайтах серия новостных сообщений о проекте.

3) Будут подготовлены и представлены на ряде международных научных конференциях доклады и презентации, раскрывающие замысел и ход реализации проекта (3-4 доклада/презентации). 
4) Будут подготовлены и опубликованы в научных журналах статьи с демонстрацией возможностей программы на конкретных примерах (46 статей).

5) Будет подготовлена и опубликована коллективная монография по итогам проекта. Издание будет размещено на тематических сайтах, а также в РИНЦ.

6) Будет разработана новая методика анализа множественных художественных переводов одного и того же текста (входящего в шекспировский канон), основывающаяся на показателях вариативности переводов (т. е. их семантического отличия друг от друга). Методика должна учесть изменчивость показателей вариативности в зависимости от того, какие переводы выбраны для сравнения; стратегию и целевую аудиторию переводчика (перевод для научного издания, текст для чтения, театральный текст); а также общие традиции художественного перевода в России XIX-XXI вв. Будет проведен концептуальный анализ тезаурусов Шекспира и переводчиков, представлен критический анализ переводов, что даст возможность вывести анализ переводов на новый методологический уровень.

Использование онлайн-программы поможет статистически выделить точки схождения и расхождения в интерпретациями переводчиками шекспировского текста, а следовательно - не только прояснить вопрос об их взаимном творческом притяжении/отталкивании, но и понять, как соотносятся «свое» и «чужое» в их индивидуальных авторских тезаурусах и коллективном тезаурусе «Русского Шекспира».

На наш взгляд, в будущем было бы целесообразно создать возможность сравнения не только одного издания оригинала с разными русскими переводами, но и добавления разных шекспировских изданий для сравнения как с русскими переводами, так и между собой. Это позволило было помочь с большей степенью доказательности говорить о том, какими изданиями пользовался тот или иной переводчик.

Таким образом, перед нами стоит большая задача. Хочется верить, что если нам удастся осуществить этот проект, он продемонстрирует возможности создания онлайн-программ для сравнительного анализа переводов на языках разных групп. Надеемся, что в будущем новые исследователи, занимающихся теорией и практикой перевода, изучением наследия других писателей, поэтов, философов, религиозных деятелей и т. д., представители самых разных национальных культур присоединятся к развитию проекта VVV.

Мы открыты для любых конструктивных замечаний и предложений, связанных с развитием данного проекта. Также будем рады, если современные переводчики или их наследники предоставят нам разрешение на использование их пе- 
реводов произведений У.Шекспира. Контактный электронный адрес: russhake@gmail.com.

\section{СПИСОК ЛИТЕРАТУРЫ}

Аникст, А. А. (1973) Шекспир. Ремесло драматурга. М. : Советский писатель. 607 с.

Гайдин, Б. Н. (2015) Разработка программы сравнительного тезаурусного анализа русских переводов произведений У. Шекспира (ответ на доклад Т. Чизмана «Текстовые массивы перевода: версия, вариация, визуализация») // Шекспир в междисциплинарных гуманитарных исследованиях : коллективная монография по материалам Международного научного семинара / ред.-сост. В. С. Макаров, Н. В. Захаров, Б. Н. Гайдин. М. : Изд-во Моск. гуманит. ун-та. 238 с. С. 147-155.

Гладких, И. (1969) Любовь тому причиной // Театральная жизнь. № 24. C. 23.

Смирнов, А. А. (1959) Примечания к тексту «Троила и Крессиды» // Шекспир У. Полн. собр. соч. : в 8 т. М. : Искусство. Т. 5 : Как вам это понравится ; Двенадцатая ночь, или Что угодно ; Юлий Цезарь ; Троил и Крессида ; Конец - делу венец. 637 с. С. 621-627.

Сумароков, А. П. (1749) Гамлет : трагедия / Александра Сумарокова. СПб. : [Печ. при Имп. Акад. наук]. 68, [1] с.

Чизман, Т. (2015) Массивы переводов и их цифровое истолкование // Шекспир в междисциплинарных гуманитарных исследованиях: коллективная монография по материалам Международного научного семинара / ред.-сост. В. С. Макаров, Н. В. Захаров, Б. Н. Гайдин. М. : Изд-во Моск. гуманит. ун-та. 238 c. C. $114-146$.

Шекспир, В. (1894) Полн. собр. соч. В. Шекспира в прозе и стихах : [в 12 т.] / пер. П. А. Каншин ; биогр. очерк В. Шекспира написан проф. Моск. ун-та Н. И. Стороженко ; примеч. П. И. Вейнберга, П. А. Каншина и др. СПб. : С. Добродеев.

Шекспир, У. (1894-1898) Шекспир в переводе и объяснении А. Л. Соколовского : [в 8 т.]. СПб. : Тип. Гл. упр. уделов.

Шекспир, У. (1902-1904) Библиотека великих писателей. Шекспир : [в 5 т.] / под ред. С. А. Венгерова. СПб. : Изд. Брокгауз - Ефрон. (Библиотека великих писателей).

Bevington, D. (1998) Preface // Shakespeare W. Troilus and Cressida / ed. by D. Bevington. Walton-on-Thames: Thomas Nelson and Sons. xxi, 469 p. P. XVI-XXI. (Arden Shakespeare, Third Series). 
Boas, F. S. (1910) Shakespere and his predecessors. Third impression. L. : John Murray. 555 p.

Cheesman, T. (2010) Shakespeare and Othello in filthy hell: Zaimoglu and Senkel's politico-religious tradaptation // Forum for Modern Language Studies. Vol. 46. No. 2. P. 207-220. DOI: $10.1093 / \mathrm{fmls} / \mathrm{cqp} 165$

Cheesman, T. (2011) Thirty times "more fair than black": Othello retranslation as political re-statement // Angermion. Vol. 4. P. 1-52.

Cheesman, T. (2015) Reading originals by the light of translations // Shakespeare Survey. Vol. 68: Shakespeare, origins and originality. P. 87-98. DOI: 10.1017/CBO9781316258736.007

Cheesman, T. et al. (2016) Five maps of translations of Shakespeare / T. Cheesman, K. Flanagan, S. Thiel, J. Rybicki // Un/translatables: New maps for Germanic literatures / ed. by B. Wiggin, C. MacLeod, Evanston, IL : Northwestern University Press. xi, 324 p. P. 253-278.

Cheesman, T. et al. (2017) Multi-retranslation corpora: Visibility, variation, value and virtue / T. Cheesman, K. Flanagan, S. Thiel, J. Rybicki, R. S. Laramee, J. Hope, A. Roos // Digital Scholarship in the Humanities. Vol. 32. Issue 4. P. 739 760. DOI: $10.1093 / 1 \mathrm{lc} / \mathrm{fqw} 027$

Cheesman, T., Roos, A. (2017) Version Variation Visualization (VVV): Case studies on the Hebrew Haggadah in English [Электронный ресурс] // Journal of Data Mining and Digital Humanities. Special issue on computer-aided processing of intertextuality in ancient languages. URL: https://jdmdh.episciences.org/ 3737/pdf [архивировано в WaybackMachine] (дата обращения: 10.12.2017).

Troilus and Cressida. Shakespeare in performance [Электронный ресурс] // Internet Shakespeare Editions. URL: http://internetshakespeare.uvic.ca/Theater/ play/Tro/\#play_performance_list [архивировано в WaybackMachine] (дата обращения: 10.12.2017).

Zakharov, N. V, Makarov, V. S., Gaydin, B. N. (2017) Russian Shakespeare repositories: Between local and global readers // Shakespeare and European theatrical cultures: AnAtomizing text and stage : Book of abstracts. 2017 ESRA Congress, European Shakespeare Research Association, 27-30 July 2017, University of Gdańsk, Gdańsk Shakespeare Theatre. Gdańsk. P. 35.

Дата поступления: 15.12.2017 2.

Гайдин Борис Николаевич - кандидат философских наук, начальник Научно-исследовательского отдела цифровых технологий Института фундаментальных и прикладных исследований Московского гуманитарного уни- 
верситета, член-корреспондент Международной академии наук (IAS, Инсбрук). Адрес: 111395, Россия, г. Москва, ул. Юности, 5, корп. 6. Тел.: +7 (499) 374-59-30. Эл. адрес: bngaydin@ mosgu.ru

Gaydin Boris Nikolaevich, Candidate of Philosophy, Head of the Research Department of Digital Technologies, Institute of Fundamental and Applied Studies, Moscow University for the Humanities; Associate Member, International Academy of Science (IAS, Innsbruck). Postal address: Bldg. 6, 5 Yunosti St., 111395 Moscow, Russian Federation. Tel.: +7 (499) 374-59-30. E-mail: bngaydin@ mosgu.ru

\section{Для циитирования:}

Гайдин Б. Н. Онлайн-программа сравнительного тезаурусного анализа русских переводов произведений У. Шекспира: итоги первого года [Электронный ресурс] // Горизонты гуманитарного знания. 2017. № 6. С. 169-182. URL: http://journals.mosgu.ru/ggz/article/view/649 (дата обращения: дд.мм. гггг). DOI: 10.17805/ggz.2017.6.10 